\title{
The psychiatric profession and the Australian government: the debate over collective depression syndrome among asylum-seeking detainees
}

This article was published in the following Dove Press journal:

Psychology Research and Behavior Management

17 November 2009

Number of times this article has been viewed

\section{William W Bostock \\ School of Government, University of Tasmania, Hobart, Tasmania, Australia}

Correspondence: William W Bostock School of Government, University of Tasmania, Private Bag 22, Hobart,

Tasmania, Australia, 001

Tel 61362262316

Fax 6I 362262864

Email bostock@utas.edu.au

\begin{abstract}
Psychiatrists have long had involvement with the political process, both individually and as a profession. They have made valuable contributions to debate over such issues as war, conflict, terrorism, torture, human rights abuse, drug abuse, suicide and other public health issues. However, they have also been complicit in some gross atrocities. Over several years there has been debate over the Australian Government's treatment of asylum seekers, and the Royal Australian and New Zealand College of Psychiatrists took the unusual step of publicly criticizing the Australian Government's policy on grounds of its toxicity leading to a diagnosis of collective depression syndrome, particularly among child detainees, but also adult detainees. The official Ministerial response was to deny that collective depression exists and to assert that the concept is meaningless. Can this intervention by psychiatrists be interpreted as a product of earlier political behaviors by psychiatrists? The willingness of psychiatrists to cooperate with other professions, notably psychologists, pediatricians, physicians and lawyers, is noted, as is presence of minority voices within the Australian psychiatric profession. The significance of the debate over the mental condition of asylum-seeking detainees is that its outcome has implications for how Australia sees itself and is seen by the rest of the world, that is, its national identity.
\end{abstract}

Keywords: collective depression syndrome, psychiatric profession, political intervention, asylum seeker, Australian national identity

\section{Introduction: psychiatrists and politics}

Psychiatrists have a long history of intervention in the political process and have made valuable contributions to debate over such issues as war, conflict, terrorism, torture, human rights abuse, drug abuse, suicide and other public health issues.

Freud, who had trained as a neurologist before founding the psychoanalytic school, expressed his concerns about the tragedy of war in his correspondence with Einstein in 1932. In that correspondence, Freud saw the violence of war as a method of conflict resolution. This followed from his understanding that within every individual and group, there exist instincts of two kinds: those that conserve and unify, which can be called erotic or sexual, and secondly, the instinct to destroy and kill, that is to say, the aggressive or destructive instinct. ${ }^{1}$ The two instincts interact and can camouflage each other.

As a result of the presence of the instinct for destruction, sometimes called by Freud Thanatos, it is easy to infect humans with war fever and hence the appeal of war as a policy. However, Freud did see one certain way to end war, and Einstein was in agreement, and this was through the establishment, by common consent, of a 
central control body supervised by a supreme court, and possessing adequate force at its disposal.

Throughout history, the treatment of mental illness has been highly variable and often problematic, ${ }^{2}$ while psychiatry as a discipline is itself a fairly recent development. ${ }^{3}$ Despite the presence of a medical ethic since the time of the Ancient Greeks, some psychiatrists have been responsible for many gross atrocities, the most infamous of which was during the Nazi regime during the 1930s and 1940s, which has been described as; "the all time low point in the history of psychiatry" and the only documented situation where a body of psychiatrists deliberately set out to exterminate patients. ${ }^{4}$ The infamous program of adult euthanasia, known as T4, after the address at its architects' headquarters in Berlin, that "involved virtually the entire German psychiatric community and related portions of the general medical community." As well as the euthanasia program, it was, according to Lifton, a psychiatrist who was the predominant medical presence in the sterilization program, and this same psychiatrist became a significant source of so-called scientific legitimation for the regime's racial policies. The atrocious behavior of those psychiatrists, who originated and implemented Nazi euthanasia policy, could be argued to be an influence on psychiatric thinking to the present day, informing a desire to intervene in contemporary political issues.

Though not believed to have been implicated in genocide, psychiatry in the Soviet Union also earned itself a very bad reputation, particularly for the labeling of psychologically healthy political dissenters as mentally unwell and in need of compulsory hospitalization and treatment. ${ }^{6}$

During and after World War II, a group of psychiatrists argued that, from a psychiatric point of view, war was not inevitable. In taking this position, they somewhat distanced themselves from the Freudian view, being rather more influenced by Dollard's "frustration - aggression thesis." ${ }^{7}$ Where aggression was seen as a response to frustration. In 1946 these psychiatrists formed a Group for the Advancement of Psychiatry (GAP), with a specific interest in focussing on the problem of war and techniques to avoid it. In 1964 they reported that war is "a social institution; it is not inevitably rooted in the nature of man." ${ }^{8}$ The organization is still active today and is now concerned with assisting in the process of adapting to terrorist attack. ${ }^{9}$

While there are some significant exceptions, it is fairly unusual for psychiatrists to become involved in political issues; in one view this is because of embarrassment over past "diagnoses", and also because of a current emphasis on biological factors. ${ }^{10}$ Another reason is that psychiatry tends to be a rather isolated discipline, while to engage in politics requires joint effort with other disciplines such as sociology and psychology. For example, the study of aggression cannot be isolated from sociological, psychological and developmental perspectives, particularly when occurring in ethnic conflict, blood feuds and wars between nations. ${ }^{11}$ Another factor working against political involvement by psychiatrists as individuals, and as a group, is the presence of many deep divisions within psychiatry itself over concepts and methods, together with philosophical and moral issues. ${ }^{12}$

\section{Australia's detainees}

Australia is a country made up of indigenous people, immigrants and the descendants of immigrants. In the 1970s and 1980s, over 100,000 "boat people", mainly from Vietnam, arrived and were satisfactorily settled. In the 1990s and early 2000s, governments decided to take a very restrictive position towards asylum-seeking arrivals, while continuing to admit a small number of refugees including some Kosovars.

Following the amendment of the 1958 Migration Act by the Labor government in $1994,{ }^{13}$ non-citizens found to be unlawfully in Australia, that is, arriving or having arrived without a visa, they were immediately detained in "administrative detention". Such detention continues until a person is determined as having a lawful reason to remain in Australia. The Act applies to all so-called "illegal" entrants regardless of age, sex, and nationality and irrespective of whether they are asylum seekers. Eight detention centers were set up in or around Australia, often in desert regions or on islands over $1000 \mathrm{~km}$ offshore. In May 2002, the total number of detainees was around 1500 persons, mostly from Africa, especially the Mahgreb, or Asia (Afghans, Chinese, Iranians, Iraqis, Kurds and Vietnamese). In addition, Australia made arrangements with two other countries, Papua New Guinea and Nauru, to provide detention camps for Australia-bound asylum seekers. ${ }^{14}$ In September 2003, there were 83 children in detention on the Australian mainland and 16 on Christmas Island, a total of 99 children out of 1117 immigration detainees. Three of the children detained on Christmas Island, four at Villawood IDC and one at Port Hedland Immigration Detention Centre were unaccompanied..$^{15}$ As of July 2009, there were 977 persons held in immigration detention, including 78 children, none of which were held in an Immigration Detention Centre). ${ }^{16}$

There was clear and confronting evidence of intense suffering of adult detainees, as highlighted by two programs from the ABC current affairs documentary series, Four Corners, ${ }^{17}$ 
and many other sources. ${ }^{18}$ However, it is the effects of detention on the mental and physical condition of children that has received special attention.

With regard to child asylum seekers held in detention centers, the Human Rights and Equal Opportunity Commission (HREOC), a body established and financed under Australian federal law, found - in its National Inquiry into Children in Immigration Detention Report - A Last Resort, tabled in Federal Parliament in May $2004^{19}$ - that Australia's immigration detention policy had failed to protect children in Australian immigration detention centers. These children had suffered numerous and repeated breaches of their human rights to mental health, to adequate health care and education, and the centers had failed to protect unaccompanied children and those with disabilities. The Commission's 2-year inquiry also found that the mandatory detention system breached the UN Convention on the Rights of the Child. Under this Convention, all children living in Australia - including children held in immigration detention - were deemed to have a right to the "highest attainable standard of health". The Convention also states on page 7 that children escaping conflict, torture or trauma have a right to special help to recover "in an environment which fosters the health, self-respect and dignity of the child." In failing to make detention a measure of "last resort", for the "shortest appropriate period of time" and subject to independent review, the Australian Government was in breach of this UN Convention.

In preparing its report, the inquiry received a wide range of evidence as to the highly harmful effect that detention has upon the mental health of some children. The inquiry was advised by many expert witnesses that whilst the children in detention received some support from mental health professionals, the detention environment was itself the source of many of the problems, with the result that child detainees had experienced, amongst other things, clinical depression, posttraumatic stress disorder (PTSD), and various anxiety disorders. More than $92 \%$ of children in detention were found to be refugees, with the implication that most, if not all of the detained children were likely to have been affected by significant traumatic episodes before they arrived in Australia. However, the inquiry received evidence that the trauma children experienced, before they arrived in Australia, did not account for the extent of mental health problems they demonstrated while in detention. In fact, the evidence was clear that immigration detention centers were not an environment which would be conducive to their recovery from the trauma of their past experience including persecution.
Reporting to the Inquiry and in reports to many other forums, a number of psychiatrists observed that children were deeply affected by witnessing violence in the detention centers, such as riots, fires, suicides, suicide attempts, incidents of self-harm and hunger strikes. ${ }^{21}$ The atmosphere of violence was compounded by other factors such as living in a closed environment and the uncertainty and sense of hopelessness concerning their future, in particular the applications for visas. As months passed without any news of their visa application, the detainees grew more depressed and fearful.

An additional factor in provoking depression among the child detainees was the strain on the family, and the fact that being in detention severely undermined the ability of parents to care for their children. The inquiry heard that parents in detention became depressed themselves, which meant their parenting skills were severely impaired such that they were unable to play with their children, read to them, supervise them or look after their safety. In some cases, parents also found it difficult to manage their children's behavior in the detention environment. The children who had been detained for lengthy periods presented significant mental health problems. A report on 20 children from a remote detention center who had been detained for an average of 28 months found that all but one child received a diagnosis of major depressive disorder and half were diagnosed with PTSD. The symptoms of PTSD experienced by the children were considered to be almost entirely related to experience of trauma in detention.

In April 2002, the South Australian Child Welfare Authority made the following report on a 13-year-old boy who had been detained for 455 days:

[He] is very withdrawn and lethargic. Since entering Woomera he has been suicidal and very sad. He reports nightmares nightly, seeing himself dead, or unable to move with people carrying his body. He reports waking screaming and finds trouble falling to sleep. He reports a diminished appetite. He has little memory of past events and no hope for the future. He refuses to make new friends because he believes they will be released but not him. He engages in constructive daytime activities but spends hours sitting staring vacantly. ${ }^{19, \text { p. } 12}$

Children in detention also self-harmed, they have sewn their lips together, attempted to hang themselves, swallowed shampoo and detergents and have cut themselves. Between April and July 2002, one child detained at Woomera made four attempts to hang himself, climbed into the razor wire four times, went on hunger strike twice 
and slashed his arm twice. Records from April 2002 report this boy saying:

If I go back to camp I have every intention of killing myself. I'll do it again and again. We came for support and it seems we're being tortured. It doesn't matter where you keep me - I'm going to hang myself. ${ }^{19, p .} 12$

\section{The RANZCP and the minister's response}

Of special interest is the intervention in the political process concerning the mandatory detention of children by the Royal Australian and New Zealand College of Psychiatrists (RANZCP), which was joined in its intervention by the Paediatric and Child Health Division of the Royal Australasian College of Physicians (RACP). These bodies called for an immediate review of the health needs of children in Australia's detention centers, in the light of evidence that the prolonged detention of children is harmful to their physical and mental health. The Colleges referred to examples of nations that have developed appropriate and humane ways to manage asylum seekers, referring in particular to Sweden which has only a brief period of detention and does not impound children. ${ }^{22}$

In a later release, the chairperson of the RANZCP went on to state:

The policy of mandatory detention in Australia contributes to the ongoing traumatization of detainees. There is clear evidence that detention is toxic for people and that mental health services cannot be delivered in these environments. The emotional and psychological damage being done to people in detention will leave them with scars which will be difficult and costly to treat. ${ }^{23}$

The call for the immediate release of children and adults who posed no immediate security risk to Australia was reiterated. ${ }^{24}$ The College of Psychiatrists noted that the length of the appeals process leads to a "collective depression syndrome" at some of the detention centers. The College did not elaborate on the symptoms of this syndrome but the UN Working Group on Arbitrary Detention indicated the following symptomatology: suicide, attempted suicide, selfmutilation, aggression, aggression and autistic reaction. ${ }^{24}$

The response of the then Minister for Immigration, Multicultural and Indigenous Affairs, Mr Phillip Ruddock (Minister until October 7, 2003), was to deny that depression is widespread within the detention centers and to question the validity of the concept of "collective depression."

I don't know what you mean by collective depression but... there are very few people (in detention centers) who have depression... The number of opportunities that people have to try and impress their claims whereby they then seek to self-harm and exhibit what some people call collective depression, has increased significantly with the number of visits (to detention centers)... When you've had periods in which there have been fewer visits, the general condition improves. ${ }^{25}$

The Minister's statement was never contradicted by the Government of which he was part, and so it can be assumed to be a statement of official policy on the mental condition of Australia's detainees including the child detainees.

\section{Depression among child detainees}

Puri et al report that depressive disorder in children is not uncommon pre-puberty though it is much more common post puberty (occurring in $0.5 \%$ to $8 \%$ of 14 - 15 -year-olds), ${ }^{26}$ while Diagnostic and Statistical Manual of Mental Disorders, 4th Edition (DSM-IV) notes that Major Depressive Disorder can begin at any age. ${ }^{27}$ In conditions of stress or trauma, such as those experienced by Australia's detained children, both before and after arrival in Australia, these figures could be expected to be much higher.

Depression can also be related to illness, pain, prolonged fatigue, and lack of human contact - deep areas of causality leaving a condition often described by the term melancholia. Even if one accepts that there is a possibility of an arbitrary nature to a diagnosis of depression, the condition of Australia's detained children would appear to be a clear cause of melancholia, and primarily environmental in origin. However, it is important to note that psychiatrists themselves are philosophically divided, some asserting the overdiagnosing of posttraumatic stress disorder is an example of the medicalizing of normal human conditions. ${ }^{28}$

While the diagnosis and treatment of depression among children remains controversial, there is agreement that it is fundamental to try to overcome any disruption to family life coming from the environment, which in the case of Australia's detained children, could only be described as one of extreme hostility.

\section{Collective depression}

The concept of collective depression is controversial because of its association with the concept of a "collective mind", as proposed by Le Bon in $1895^{29}$ and further developed by Durkheim as "collective consciousness". ${ }^{30}$ Le Bon advanced a "contagion theory" that crowd behavior takes control over individual behavior through the infectious spread of emotion and action. This view has been contested by those who argue 
for an emergent-norms theory that sees any kind of group mind as an illusion or "hypothesized, collective, transcendent spirit or consciousness". ${ }^{31}$ The methodological difficulty of assessing any concept of group mind has meant that it has fallen outside mainstream social science discussion, with the result that there is very little research currently being undertaken. $^{32}$

From a medical perspective some writers have addressed this question in terms of "mass sociogenic illness" in which epidemic hysteria is spread, as if by contagion, as a result of fear and uncertainty. ${ }^{33}$ Others have tended to leave open the question of the collective mental state: for example Cawte stated that a "sick society" is one with a high amount of psychiatric illness. ${ }^{34}$ Without assuming the concept of a group mind, it is thus possible to state that collective depression can exist, ie, when a large proportion of the members of a society are depressed, that is, are displaying signs of inadequacy, despondency, lack of vitality, pessimism, sadness and dependency upon substance ingestion and calling for help through self-mutilation and suicide attempts. $^{35}$

\section{Beyondblue}

In 2000, the Australian Government in conjunction with the Victorian Government (and with the later support of other State and Territory governments, private companies and community-based organizations), created beyondblue, a national program to treat depression, which was seen as reaching epidemic proportions among the Australian population. ${ }^{36}$

This program is based on an official acknowledgement that around one million Australian adults and 100,000 young people live with depression each year. Depression is estimated to cost the Australian community over AUD600 million each year and is currently the leading cause of non-fatal disability in Australia. Moreover, depression will be second only to heart disease as the leading medical cause of death and disability within 20 years. To the present, beyondblue seems to be concentrating on individual depression, by promoting awareness of the condition and urging individual sufferers to seek medical treatment. Thus while the government denied that depression (other than that caused by the visits of psychiatrists and other health care professionals) exists in detention centers, it was prepared to acknowledge the prevalence of widespread depression in the general community. After acknowledging that the definitions of depression used by psychiatrists and beyondblue might legitimately differ, the position of the then Minister does seem to indicate a political dimension to the subsequent public debate.

\section{Treating collective depression}

While individual depression can be successfully treated, collective depression, being a different order of problem, cannot be treated by therapies for individuals but must be treated at the systemic level, specifically by leadership, as observed by Forsyth. ${ }^{37}$ The function of groups with a position of leadership within the community, such as the psychiatric profession, (as well as many other groups, notably psychologists, pediatricians, physicians, lawyers, academics and religious authorities), in treating collective depression is to assess the obvious causes of the depression and then to demonstrate that the situational factors can be changed, starting with small symbolic ways, if only with those few that are possible, and to show a leadership role by speaking out as a bystander.

The Australian psychiatric profession showed a willingness to accept this role with its clear statement that detention is toxic. Here the use by the RANZCP of the concept of toxicity is noteworthy. The term has long been used in relation to the physical toxicity of drugs and other chemicals and physical agents, but only rarely in relation to the behavioral effects of the influence by other agents. ${ }^{38}$ Psychiatrists are now drawing upon the work of organizational theorists who have labeled certain harmful effects of organizational operation, such as poor leadership, as toxic, in other words, poisonous in effect. ${ }^{39}$ In proposing the approach of detoxification of the psychological environment, it can also be noted that organizational theory has relevance in the case of children and adults held in Australia's detention centers.

In their quest for a community leadership role, the RANZCP willingly cooperated with many other specializations, professions, and members of the community from a wide variety of backgrounds. Individual psychiatrists also took an active community leadership role. ${ }^{40}$ However, the role of the College in this public debate has not been without its internal critics from among psychiatrists and members of other branches of the medical profession. In an article in Australian Psychiatry, Dr Samuell Doron made the following statement.

We have gone from being concerned about children in detention centres to being active opponents of the centres and direct opponents of the government.... Is the evidence for inadequate health facilities to detainees convincing? Do we blame the parents for protracted appeals that keep the children in detention? Should we be worried about 
the way that children are being manipulated into violent demonstrations in the detention centres or more worried about how they have been used in school-based campaigns against government policy? Do we have a uniform and homogeneous view within the College about how government should protect its borders? ${ }^{41}$

Writing in the Medical Journal of Australia, another medical writer, Dr Debra Graves, expressed opposition to the publication of an article written by a medical doctor who was himself a detainee, on the grounds that the detained doctor had a "potential bias" concerning his treatment by the "democratically elected government of this country." 42

\section{Conclusion}

The asylum seeker debate can be interpreted on one level as a battle over the diagnosis of the collective depression syndrome amongst detained child and adult asylum seekers, and on another as one over the philosophical status of this syndrome. However, there is a deeper implication as to how Australia should see itself and how it should be seen by the rest of the world, that is, its national identity be understood.

For its own reasons, the Australian Government of the day officially denied the existence of a collective depression among the asylum-seeking detainees while at the same time seeing fit to acknowledge and fund a program for the treatment of depression among a large percentage of the non asylum-seeking population, including 100,000 young people.

On the other side of the debate was the psychiatric profession's representative College, though with some members dissenting over philosophical and political issues. The RANZCP appealed to the Australian community to recognize and rectify the mistreatment of children and adults by a government that acts in their name. In this activity, they worked with many groups and individuals from outside their profession

The debate over the presence of a collective depression syndrome amongst child and adult asylum-seeking detainees thus also had political, philosophic and moral dimensions as well as medical ones. With this debate, another chapter in the long history of psychiatry's relationship with politics has been written and Australia's quest for national identity has continued.

\section{Note}

An earlier version of this paper was first presented at the 20th IPSA World Congress, Session (RC29) Psychopolitics, Fukuoka, Japan, July 11, 2006. The writer gratefully acknowledges the valuable comments of four anonymous reviewers.

\section{Disclosure}

The author reports no conflicts of interest in this work.

\section{References}

1. Freud, in Nathan O, Norden H eds. Einstein on Peace. New York: Schocken Books; 1960:7. http://www.idst.vt.edu/modernworld/d/ Einstein.html Retrieved September 30, 2003.

2. Foucault M. Madness and Civilization: a History of Insanity in the Age of Reason. New York: Vintage Books; 1988.

3. Shorter E. A History of Psychiatry: From the Era of the Asylum to the Age of Prozac. New York: John Wiley \& Sons; 1997.

4. Dudley M, Gale F, Psychiatrists as a moral community? Psychiatry under the Nazis and its contemporary relevance. Aust NZJ Psychiatry. 2002;38:585-594.

5. Lifton RJ. The Nazi Doctors, medical killing and the psychology of genocide. New York: Basic Books; 1986:65.

6. Bloch S. Reddaway P. Russia's Political Hospitals, The Abuse of Psychiatry in the Soviet Union. London: Gollancz; 1977.

7. Dollard J. Frustrations and Aggressions. With Miller NE, Doob LW, Mowrer OH. Sears RR. in collab. with Ford CS. Hovland, CI. Sollenberger RT. New Haven: Pub. for the Institute of Human Relations by Yale University Press; 1939.

8. Rogow AA. Psychiatry and Political Science: Some Reflections and prospects. In: Lipset SM. ed. Politics and the Social Sciences. New York: Oxford University Press; 1969:213.

9. GAP, 2003. Group for the Advancement of Psychiatry. URL http://www. groupadpsych.org/Accessed September 30, 2003.

10. Shore MF. How Psychiatrists and Political Scientists Have Grown Up since 1938. Psychiatry: Interpersonal and Biological Processes. 2001;64 (3):192-196.

11. Haig RA. The Psychiatrist and War. Psychiatr Bull R Coll Psychiatr. 1991;15:203-204.

12. McHugh PR. How psychiatry lost its way. Commentary. 1999;(Dec) 12:32-38.

13. Commonwealth, Migration regulations, 1994. URL http://www.austlii. edu.au/au/legis/cth/consol_reg/mr1994227/ Accessed October 16, 2009.

14. UN (United Nations). News Service, 2002. UN Working Group on Arbitrary Detention. URL http://www.hrea.org/lists/refugee-rights/ markup/msg00080.html Accessed December 1, 2003.

15. Parliamentary Library, (Australia), Children in Detention. E-Brief: Online Only issued 13 October 2003; updated 23 November 2005. Canberra: Parliament of Australia. URL http://www.aph.gov.au/library/ intguide/SP/Childrendetention.htm Accessed August 14, 2007.

16. Department of Immigration and Citizenship (Australia). Managing Australia's Borders, Immigration Detention Statistics for 24 July 2009. URL http://www.immi.gov.au/managing-australias-borders/detention/_ pdf/immigration-detention-statistics-20090724.pdf.

17. $\mathrm{ABC}$ (Australian Broadcasting Commission). The Queue Jumpers, Four Corners, first broadcast on $\mathrm{ABC}$ TV, October 16 and $\mathrm{ABC}$ (Australian Broadcasting Commission), 2002. To Deter and Deny, Four Corners, first broadcast on ABC TV, April 15.

18. Bilboe, HA. Asylum Seekers in Australia: Turning Repression and Stress into Longterm Anxiety and Depression. In: Warren B. ed. Suffering the Slings and Arrows of Outrageous Fortune, International Perspectives on Stress, Laughter and Depression. Amsterdam, New York: Rodopi; 2007:123-136.

19. HREOC (Human Rights and Equal Opportunity Commission). Report - A Last Resort? Inquiry National Inquiry into Children in Immigration Detention, Summary. 2004. URL http://www.hreoc.gov. au/human_rights/children_detention_report/summaryguide/8_mental. htm Accessed May 20, 2004. 
20. United Nations, UNICEF, Convention on the Rights of the Child. URL http://www.unicef.org/crc/ Accessed October 16, 2009.

21. Silove D. The asylum debacle in Australia: a challenge for psychiatry. ANZJ Psychiatry. 2002;36(3):290-296.

22. RANZCP. (Royal Australian and New Zealand College of Psychiatrists). Child health specialists call for independent review of the health needs of children in Australian detention centres, August 17, 2001 \#1 URL http://www.ranzcp.org/publicarea/media2001.asp Accessed April 25, 2006.

23. RANZCP. (Royal Australian and New Zealand College of Psychiatrists). 2002. 'Child Health Specialists Call for Independent Review of the Health Needs of Children in Australian Detention Centres. Media Release, October 23. URL http://www.ranzcp.org/publicarea/ media2002.asp Accessed April 25, 2006.

24. RANZCP. (Royal Australian and New Zealand College of Psychiatrists), 2003. 'RANZCP airs deep concern at the mandatory detention of child asylum seekers', November 11. URL http://www.ranzcp.org/publicarea/ media2003.asp Accessed April 25, 2006.

25. Ruddock, The Hon. P. Philip Ruddock on Detention Centres. The Age (Newspaper), June 7, 2002. p. 4.

26. Puri BK, Laking PJ Treasaden IH. Textbook of Psychiatry. Edinburgh, London, New York, Philadelphia, Sydney, St. Louis, Toronto: Churchill Livingstone; 1996:298.

27. American Psychiatric Association. Diagnostic and Statistical Manual of Mental Disorders (4th edn text revision) (DSM-IV TR). Washington, DC: APA, 2000:372.

28. McHugh PR. How Psychiatry Lost its Way, Commentary. 1999;(Dec) 12:32-38.

29. Le Bon G. The Mind of the Crowd. (First Published 1895). New York: Viking; 1960.

30. Durkheim E. The Rules of Sociological Method. New York: Free Press and London: Collier-Macmillan; 1964:103n.
31. Reber AS. The Penguin Dictionary of Psychology (2nd ed). London, New York, Ringwood, Toronto, Auckland: Penguin; 1995:323.

32. Varvoglis MP. Conceptual frameworks for the study of transpersonal consciousness. World Futures. 1997;48:105-114.

33. Bartholomew RE, Wessely S. Protean nature of mass sociogenic illness: From possessed nuns to chemical and biological terrorism fears. $\mathrm{Br} \mathrm{J}$ Psychiatry. 2002;180:300-306.

34. Cawte JE. A Sick Society. Kearney GE, de Lacey PR, Davidson GR. Eds. In: The Psychology of Aboriginal Australians.. Sydney, New York, London, Toronto: J. Wiley \& Sons; 1973:365-379.

35. Steel Z. Summary evidence regarding the psychological damage caused by long term detention, MAPW Position Paper, 2002. URL http://www.mapw.org.au/refugees/02-07-03steel-psych.html Accessed December 1, 2003.

36. beyondblue. The National Depression Initiative (Australia), 2004. URL http://www.beyondblue.org.au/index.aspx Accessed August 30, 2004.

37. Forsyth DR. Interfacing Social and Clinical Approaches to Mental Health. Grand Rounds Presentation, Virginia Commonwealth University, February 9, 1996. http://www.vcu.edu/hasweb/pzy/faculty/fors/grand html Accessed August 30, 2000.

38. Saxena PN. Behavioural toxicity. Indian J Pharma. 1974;6(2): $81-86$.

39. Hirschhorn L. Leaders and followers in a post-industrial age: a psychodynamic view. J Appl Behav Sci. 1990;26(4):529-542.

40. Mares S, Newman L. (eds.). Acting from the Heart: Australian Advocates for Asylum Seekers Tell their Stories. Sydney: Finch Publishing; 2007.

41. Doron S. Speaking on behalf of the College: the politics of children or childish politics? Australas Psychiatry. 2003;11(2):121-122.

42. Graves D. Letter to the Editor: Asylum seekers and healthcare. Med $J$ Aust. 2002;176(2):86-87.

\section{Publish your work in this journal}

Psychology Research and Behavior Management is an international, peerreviewed, open access journal focusing on the science of psychology and its application in behavior management to develop improved outcomes in the clinical, educational, sports and business arenas. Specific topics covered include: Neuroscience, memory \& decision making; Behavior

\section{Dovepress}

modification \& management; Clinical applications; Business \& sports performance management; Social and developmental studies; Animal studies. The manuscript management system is completely online and includes a quick and fair peer-review system. Visit http://www.dovepress. com/testimonials.php to read real quotes from published authors. 